\title{
ARTICLE
}

\section{Dealing with dynamics and uncertainty of small pelagic fisheries: bioeconomic analysis of manager's responses to alternative management strategies}

Tratando con dinámica e incertidumbre de pesquerías de pelágicos menores: análisis bioeconómico de respuesta del administrador ante diferentes estrategias de manejo

\section{Juan Antonio De Anda-Montañez', Silvia Salas² and Gabriela Galindo-Cortes ${ }^{3}$}

\author{
'Centro de Investigaciones Biológicas del Noroeste, S.C., Av. Instituto Politécnico Nacional 195, Col. Playa Palo de Santa Rita Sur, C.P. \\ 23096, La Paz, Baja California Sur, México.jdeanda @ cibnor.mx \\ ${ }^{2}$ Centro de Investigación y de Estudios Avanzados, Instituto Politécnico Nacional, Unidad Mérida, Antigua Carretera a Progreso Km. 6, \\ Cordemex, C.P.97310, Mérida, Yucatán, México. marquezs.silvia@gmail.com \\ ${ }^{3}$ Instituto de Ciencias Marinas y Pesquerías, Universidad Veracruzana, Calle Hidalgo 617, Col. Río Jamapa, C.P. 94290, Boca del Río, \\ Veracruz, México.ggalindo06@gmail.com
}

Resumen.- Las pesquerías de pelágicos menores se han caracterizado por sus grandes fluctuaciones en abundancia, debido a factores ambientales, regímenes de captura, patrones de reproducción, entre otros. Dada esta complejidad, el desarrollo de esquemas de manejo para la pesquería de sardina requiere de la evaluación del impacto de diferentes estrategias de manejo, considerando la incertidumbre asociada con el comportamiento biológico de los recursos y el rendimiento económico de las pesquerías. Una forma de predecir dichos cambios en la abundancia, es a través de procesos de simulación bajo diferentes escenarios. En este estudio, se usó un modelo bioeconómico dinámico estructurado por edad de la pesquería de sardina del Pacífico (Sardinops sagax) de la península de Baja California en México para evaluar el efecto de cambios en el reclutamiento sobre diferentes variables de estado (biomasa, valor presente neto y captura). Se consideró riesgo e incertidumbre asociada a parámetros sensibles (mortalidad natural, precio y capturabilidad). Se empleó el enfoque precautorio para evaluar la respuesta de los responsables de tomar decisiones con diferente actitud al riesgo (adverso, neutral y buscador de riesgo) bajo diferentes escenarios, desde acceso abierto hasta restricciones en el esfuerzo pesquero. Los resultados mostraron que las estrategias de manejo que involucraron restricciones en el esfuerzo pesquero resultaron en una baja probabilidad (0-7, expresado en porcentaje) de exceder los puntos de referencia límite (PRL) comparado con aquellas bajo condiciones de acceso abierto o captura en rendimiento máximo sostenible (RMS) y cuotas de captura (13-60\%). El análisis enfatiza las ventajas de utilizar un enfoque que incorpore el riesgo y la incertidumbre para la generación de estrategias de manejo de las pesquerías pelágicas con alta exposición a condiciones inciertas.

Palabras clave: Puntos de referencia bioeconómico, manejo precautorio, sardina del Pacífico, riesgo, incertidumbre

Abstract.- Small pelagic fisheries have been characterized by large fluctuations in abundance due to environmental factors, harvest regimes, and reproduction patterns, among others. Given this complexity, the development of management schemes for sardine fisheries requires an evaluation of the impact of different management strategies. The evaluation of any management scheme would need to account for the uncertainty associated with the biological behavior of resources and economic performance of the fisheries to predict changes in resource abundance through simulation of alternative scenarios. In this study, an agestructured dynamic bioeconomic model of the Pacific sardine (Sardinops sagax) fishery off the Baja California peninsula in Mexico was used. The model assessed the effect of changes in recruitment over several state variables (biomass, net present value and catch). An analysis of risk and uncertainty allowed the identification of sensitive parameters (natural mortality, price and catchability) and a precautionary approach was used to evaluate the response of decision-makers with different attitudes toward risk (adverse, neutral and prone) given different management scenarios, from open access to restrictions in fishing effort. Incorporation of uncertainty and risk analyses into the assessment of the sardine fishery showed that management strategies that involve restrictions on fishing effort resulted in a lower probability (0-7, expressed in percentage) of exceeding limit reference points (LRPs) than those strategies that permit conditions of open access, or that aim for catch at maximum sustainable yield (MSY) and catch quotas (13-60\%). The analysis highlights the advantages of using an approach that incorporates risk and uncertainty for generating management strategies for pelagic fisheries with high exposure to uncertain conditions.

Key words: Bioeconomic reference points, precautionary management approach, Pacific sardine, risk, uncertainty 


\section{INTRODUCTION}

Managers of fisheries face challenging tasks such as making choices among alternative management options while monitoring the status of the resources, the performance of the fisheries and the response of fishermen. The task increases in complexity when resources are highly vulnerable to environmental conditions like in the case of pelagic fisheries. Under this context, technical support with sound information for making 'the best' decisions are indeed required. Nevertheless, what could be the 'best decision'? Any decision has to make some assumptions based on the technical assessment, but also based on the manager's criteria and other influential environmental conditions (social, economic, etc.). Bioeconomic models are useful for assisting managerial decisions as they not only incorporate uncertainty associated with the dynamics of the resources and the fishery, but also the effect of decision makers given their different attitudes toward alternatives options. Hence the trial and error of decisions can be forecasted, giving a portrait of the 'best' and 'worst' case scenarios of alternative decisions, allowing an understanding of the system's dynamics and also to get feedback on the response of resources to alternative fishery policies (Prellezo et al. 2009, Anderson \& Seijo 2010, Ivar 2010).

Different types of bioeconomic models have been developed for fisheries, among them age-structured models have received special attention due to their usefulness in describing the complexity of the fisheries and fish stocks. These models have been used mainly for simulation and numeric optimization (Clark 1990, Tahvonen 2010). A variety of bioeconomic age-structured models have been developed for several types of fisheries (Wilen 2000, Pintassilgo \& Duarte 2002, Smith \& Wilen 2003, Massey et al. 2006, Grafton et al. 2007, Smith et al. 2008, Tahvonen 2008). Among those models, simulation models that comprise biological, environmental, and economic factors, although less common, allow for the evaluation of the bioeconomic impact of several management strategies offering important tools in fisheries resource management (Seijo et al. 2004, De Anda-Montañez et al. 2010).

As stated earlier, many of the important multispecies fisheries in the world include small pelagic fish, like Pacific sardine (Sardinops sagax), Peruvian anchoveta (Engraulis ringens), and Southern African pilchard (Sardinops sagax). There are several models that have been developed for this type of fishery. For sardine stocks specifically, the need of the precautionary approach in stock assessment and management is necessary due to the uncertainty associated with the resource and the dynamics of the fishing fleet. It is also important to quantify the risk related to decision making associated with the selection of limit reference points (LRPs) and target reference points (TRPs) (Hilborn 2010) to avoid undesirable situations and reduce the probability of stock collapse.
Decision theory can be used to measure the risk associated with the selection of management strategies given imperfect knowledge of nature (the resource and its environment, the dynamics of fishing effort), and the uncertainty associated with the decision-making process. The incorporation of risk and uncertainty into fisheries assessment and management has become a demand as uncertainty increases around many fisheries. On the other hand, the precautionary approach (Caddy \& Mahon 1995, Seijo et al. 1997a, b) can be coupled with decision theory approaches (Anderson \& Seijo 2010) for defining LRPs and TRPs according to the context of the fishery to be assessed (goals of decision makers and conditions of the resources) with the objective of obtaining more than the maximum sustainable yield (MSY) (Larkin 1977). Concepts and practices that implicate the MSY as a TRP have been shown to be insufficient. By the mid-1990s the United Nations unified the MSY and the precautionary approach: 'The fishing mortality rate which generates MSY should be regarded as a minimum standard for limit reference point' (Caddy \& Mahon 1995, Da Rocha et al. 2012).

In Mexico, the development of management plans for fisheries requires performance measures to evaluate alternative management procedures. The Pacific sardine (Sardinops sagax) fishery has been mainly exploited in the western coast of the Baja California peninsula and within the Gulf of California. In both locations, there were large fluctuations in fishery yields during the 1991-1992 and 1992-1993 fishing seasons; the social and economic impacts of such fluctuations in the Gulf of California fishery have been analyzed by bioeconomic modeling (Cisneros-Mata et al. 1995, De Anda-Montañez \& Seijo 1999). However, most of the studies of the Pacific sardine off the western coast of the Baja California peninsula (Fig. 1) have focused on biological components (Félix-Uraga 1990, 1992; Morales-Bojórquez 1999, 2002; Félix-Uraga et al. 2004) or, in some cases, on the effect of environmental factors on the stock and hence the fishery (Morales-Bojórquez et al. 2003, Galindo-Cortés et al. 2010). Approaches using bioeconomic modeling and risk evaluation have been seldom undertaken for the Pacific sardine in this region while they have been more frequently used in other regions of the country and worldwide (Seijo et al. 2004, Álvarez-Dias \& Dominguez-Torreiro 2006, Seijo \& Caddy 2008, Silvestri \& Maynou 2009, Mullon et al 2009, Prellezo et al. 2009, Tahvonen 2010, Politikos et al. 2013).

In the present study risk and uncertainty are incorporated in the analysis of the sardine fishery from BCS in Mexico to learn about the effect of alternative policy options over a highly fluctuating fishery accounting for the effect on the stock and the economic performance of the fishery. Alternative scenarios within 

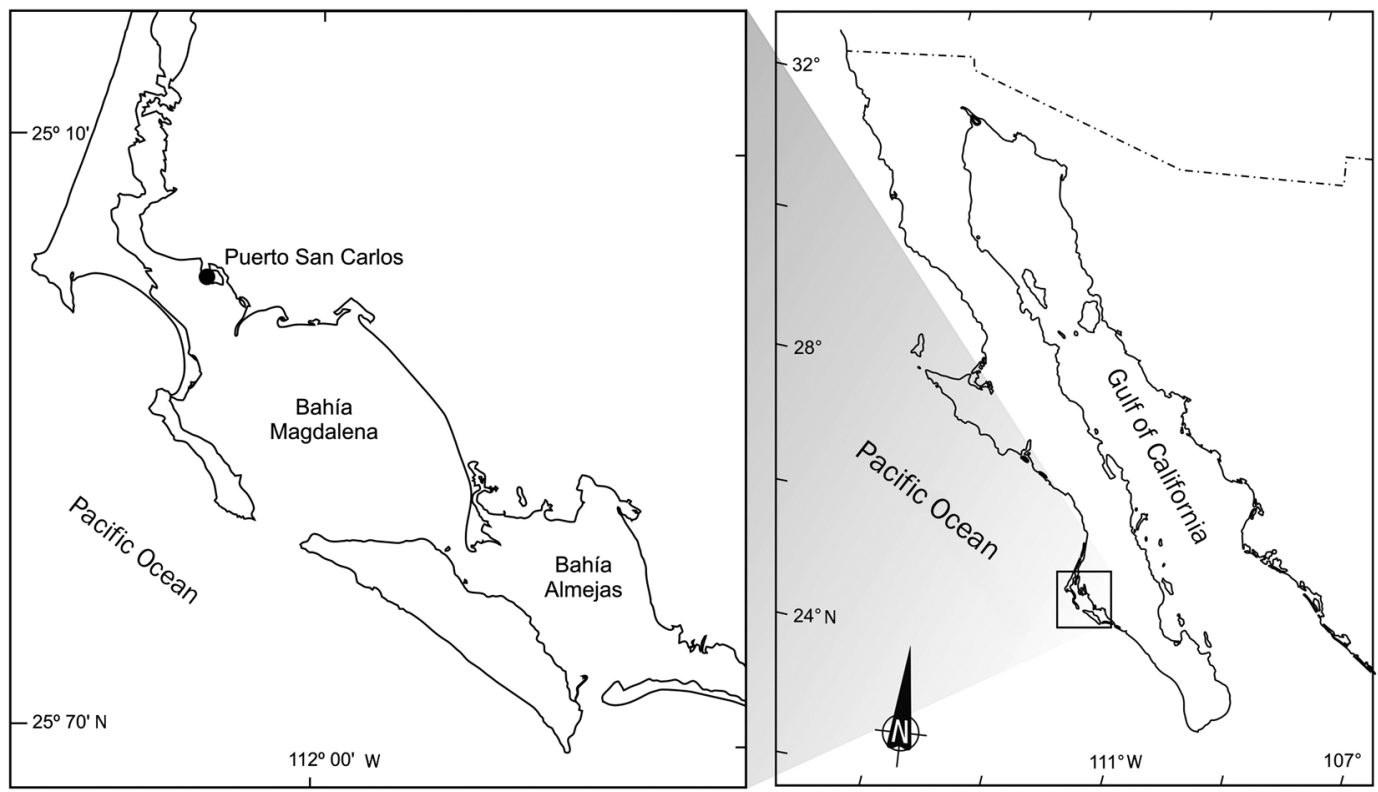

Figure 1. Study area showing the zone of operation of the Pacific sardine (Sardinops sagax) fishery in the southern portion of the west coast of the Baja California peninsula, Mexico / Área de estudio mostrando la zona de operación de la pesquería de sardina del Pacífico (Sardinops sagax) en la porción sur de la costa oeste de la península de Baja California, México

the fishery were forecasted to evaluate the effect of changes in management strategies over biological and economic state variables (biomass, catch, and net present value), under the assumption that different states of nature (recruitment variability due to environmental factors, fluctuating natural mortality, among others) can take place; the MSY was used as a LRP and the maximum sustainable economic yield (MEY) as an economic TRP.

\section{Materials AND Methods}

\section{DATA SET}

Information from 22 fishing seasons of the sardine fishery in BCS (1983 to 2004) was used in this study; information comprises data from annual yields (ton), and fishing effort (fishing-days). Cost and revenue data were obtained from direct interviews with fishermen, and fishing fleet owners from the San Carlos and Adolfo López Mateos ports in Baja California Sur. The price was computed as a weighted average price for packaged and processed target and non-targeted species.

\section{BIOECONOMIC MODEL}

The bioeconomic model is described in Appendix 1 and previously published in De Anda-Montañez et al. (2010). The bioeconomic model was developed to simulate management strategies that assume (1) the effect of density-dependence on recruitment is described by an environmentally driven stock recruitment function (eq. 4, Appendix 1); (2) changes in fishing effort respond to revenue (eq. 6, Appendix 1); (3) values of the instantaneous rate of natural mortality $(M)$ and catchability coefficient $(q)$ are constant through age and time; (4) mortality due to fishing is a dynamic function of the fishing effort; (5) variable costs change with changes in fishing effort, and fixed costs depend on the invested capital; and (6) migration was neglected in the model.

\section{Alternative SCEnarios fOr management STRATEgies}

The alternative scenarios that were forecasted with the bioeconomic simulation model to assess the effect on the Net Present Value (NPV) include the following alternative management options:

1) Open access (base run), catch and effort levels calculated during the period 1983-2004;

2) Effort at the maximum sustainable economic yield ( $\mathrm{f}_{\mathrm{MEY}}=$ 756 trips), which can be reached when differences between $T R$ and $T C$ are maximized; this value was calculated from the base run in the year 2001; 
3) Catch at maximum sustainable yield $\left(\mathrm{C}_{\mathrm{MSY}}=45,800\right.$ ton $)$, is the maximum catch calculated from the same base run, but in the year 2002;

4) Effort observed in $2004\left(\mathrm{f}_{2004}=851\right.$ trips), last analyzed season; and

5) Catch quota (CQ) allocated at 40,000 ton, based on the values of the catch obtained in the year $2001\left(\mathrm{CQ}_{40,000}\right)$.

The $\mathrm{f}_{\mathrm{MEY}}, \mathrm{C}_{\mathrm{MSY}}, \mathrm{CQ}_{40,000}$ come from the base run, incorporating the observed effort in 2004, and hence in order to learn about the behavior of the fishery under alternative scenarios, the model was run starting with the simulations from 2005 fishing season; a simulation was run to forecast patterns up to 2017. The input parameters for the bioeconomic model with its corresponding references are shown in Appendix 2.

\section{Sensitivity anALYSeS}

A sensitivity analysis was performed for each of the 5 strategies by introducing variation in some parameters and their effect over biomass, catch, and $N P V$ for a given rate of discount $(\delta)$, which in this study was 0.04 year $^{-1}$. The parameters modified for the sensitivity analysis included: unit cost of effort $(U c)$, catchability coefficient $(q)$, average price for Pacific sardine $\left(P_{p s}\right)$, density-independent coefficient of the stock-recruitment Ricker's equation $(a)$, density-dependent coefficient of the stock-recruitment Ricker's equation $(b)$, growth coefficient of the von Bertalanffy equation $(K)$, natural mortality rate $(M)$, and fleet dynamics parameter $(\varphi)$. The fleet dynamics parameter indicates the entry-exit of the fleet, which was assumed to be greater than zero (if $\varphi$ is equal to zero, then effort is assumed constant throughout time) (Equation 6, Appendix 1). Given the uncertainty around different parameter estimates of the bioeconomic model, generation of data testing potential scenarios of variability around that deterministic estimate can be more informative for management decisions (Anderson \& Seijo 2010). In this sense, Monte Carlo analysis offers a platform to do so. In this study variation around $( \pm 20 \%)$ of the biological parameters was assumed appropriate to test the 5 management strategies.

\section{DECISION ANALYSIS WITHOUT MATHEMATICAL PROBABILITIES}

In the absence of mathematical probabilities that predict the occurrence of a particular event, trends in fisheries can be evaluated when alternative management strategies are implemented. These trends can result from a set of combinations of alternative states of nature associated to the fishery and a set of criteria according to the aims and perspectives of managers. Hence, one can consider the possible outcomes of decisions due to differences in the mangers preferences when defining such strategies. According to Seijo et al. (1997b) and Anderson $\&$ Seijo (2010), three different types of managers can be classified depending on different levels of risk aversion: (1) A highly cautious manager adverse to risk that is willing to lose the least; (2) A moderately cautious manager that will try to minimize the maximum regret from the maximum loss of opportunities of each management strategy; and (3) A broadly optimistic manager that would select the strategy that maximizes his benefits.

In the first case, the Maximin criterion was considered, which is based on the decision table approach and calculates a vector of the minimum values for the performance variable (NPV, biomass, and catch in this case) resulting from each management strategy; the decision includes the selection of a strategy that involves the maximum value of the observed minimum for the performance variable (Seijo et al. 1997b, Anderson \& Seijo 2010). Because $P_{p s}$ and $q$ were two of the parameters to which the model was more sensitive, and $M$ is one of the most important parameters in population dynamics, the states of nature selected for testing different scenarios were based on changes of these three parameters when running the analysis of alternative strategies defined as State 1, $M=0.6$; State 2, $M=0.48$; State 3, $M=0.72$; in all three states $P_{p s}$ and $q$ were assumed as constant $\left(P_{p s}=52.6 \mathrm{USD}^{-1}\right.$ and $\left.q=0.000155\right)$.

In the second case the Minimax regret criterion applies, whereby a manager would select the strategy that would involve less 'regret', e.g. when the difference between the real benefit and the benefit that could have been obtained if the correct decision had been made is smaller (Seijo et al. 1997b, Anderson $\&$ Seijo 2010). The states of nature were defined as State 4 , $P_{p s}=52.6 \mathrm{USD}^{-1}$ ton $^{-1}$ State $5, P_{p s}=42.08 \mathrm{USD}$ ton $^{-1}$; State 6, $P_{p s}=63.12 \mathrm{USD}^{-1}$; in these 3 states $M$ and $q$ were assumed as constant $(M=0.6$ and $q=0.000155)$.

Finally, in the third case the Maximax criterion applied, in this case the manager would select the maximum value from a vector of the maximum values for the performance variable from each management strategy (Seijo et al. 1997b, Anderson \& Seijo 2010). The states of nature were defined as State 7, $q=$ 0.000155 ; State $8, q=0.000124$; State $9, q=0.000186$; in these last three states $M$ and $P_{p s}$ were assumed as constant $\left(M=0.6\right.$ and $P_{p s}=52.6 \mathrm{USD}$ ton $\left.^{-1}\right)$

Besides, the rate of discount was tested over different assumptions as suggested by Anderson \& Seijo (2010). The states of nature were defined as State $10, \delta=0.04$; State $11, \delta$ $=0.02$; State $12, \delta=0.06$; in these last three states of nature all parameters were assumed as constant. 


\section{Monte Carlo analysis}

In order to evaluate the probability of exceeding the LRP and TRP of the performance variables, which in this case include biomass, catch, and Net Present Value (NPV), a Monte Carlo analysis was performed to account for different sources of uncertainty and its impact on the biological and economic fishery subsystems. In this study, seven parameters were tested to evaluate which one could affect the most performance variables, given the LRP and TRP of such parameters; unit cost of fishing effort $(U c)$, average price for Pacific sardine $\left(P_{p s}\right)$, densityindependent coefficient of the stock-recruitment Ricker's equation $(a)$, density-dependent coefficient of the stockrecruitment Ricker's equation (b); these 4 parameters are assumed to have a log-normal error distribution (Pennington 1996, Jiao et al. 2004), and the parameters catchability ( $q$ ), growth of the von Bertalanffy equation $(K)$, and natural mortality rate $(M)$ were assumed to have a normal error distribution, allowing for change simultaneously in the Monte Carlo analysis. The number of runs performed was 10,000.

Traditionally, TRPs have been defined as a desirable objective for management, while LRPs indicate a state of a fishery and/or resource that is considered undesirable and which management action should be avoided (Caddy \& Mahon 1995). In the present study, an acceptable risk of reaching those LRPs is expressed in terms of risk below $10 \%$.

The MSY in terms of biomass at maximum sustainable yield $\left(\mathrm{B}_{\mathrm{MSY}} ; 274,741\right.$ ton $)$ and catch at maximum sustainable yield $\left(\mathrm{C}_{\mathrm{MSY}} ; 45,800\right.$ ton $)$ were used as a LRP; the biomass at the maximum economic yield ( $\mathrm{B}_{\mathrm{MEY}} ; 375,035$ ton $)$ and the catch at $2 / 3$ of maximum sustainable yield $\left(\mathrm{C}_{2 / 3 \mathrm{MSY}} ; 30,533\right.$ ton $)$ were used as TRPs. Here, it was assumed that the maximum sustainable economic yield (MEY) was equivalent to \$112,298 USD (De Anda-Montañez et al. 2010), which occurs at the effort level yielding the greatest margin between total costs and sustainable total revenues for the resource (Clark 1990, Seijo et al. 1997a) and hence the aim would be to maximize the $\mathrm{NPV}$. Also, the bioeconomic equilibrium point (BE) for an open access fishery in which total revenue equals total cost under equilibrium conditions (Caddy \& Mahon 1995, Seijo et al. 1997b) was adopted as an LRP (EB= $\$ 0.0$ USD).

These decisions on acceptable risk and the LRPs are arbitrary, but it is important that managers recognize them (Caddy \& Mahon 1995). The current management measures for the Pacific sardine fishery off the western coast of the Baja California peninsula are: minimum legal catch size $(150 \mathrm{~mm}$ standard length), the limited entry of new permits to the fishery depending on the storage capacity, the maximum size of purse seines is proportionally determined according to the boat size, and a recommended exploitation rate of 0.25 (DOF 2012) ${ }^{1}$. But LRPs have not been proposed for the fishery. The dynamic bioeconomic model used for this analysis is described in Appendix 1 (De Anda-Montañez et al. 2010).

\section{Results}

The bioeconomic age-structured model used in this study has been previously described and validated for sardine in the Baja California peninsula by De Anda-Montañez et al. (2010). However, it did not include a sensitivity analysis nor the integration of risk analysis, which is presented here based on decision tables calculated without mathematical probabilities, using the Maximin, Minimax, Maximax criteria, and considering the five management strategies with nine states of nature (defined here as State 1 to State 9) accounting for changes in values of natural mortality $(M)$, price $\left(P_{p s}\right)$, or catchability $(q)$. In addition, the probabilities of exceeding the values used as LRPs and TRPs for the biomass, catch and NPV for each of the different simulated strategies are also presented in this study.

\section{Sensitivity anALYSES}

The parameters that the model considered to be more sensitive, in general, were unit cost of fishing effort $(U c)$, catchability coefficient $(q)$, price for target species $\left(P_{p s}\right)$, and the parameters of the stock-recruitment Ricker's equation (density-independent ( $a$ ) and density-dependent (b) coefficients). This observation was true for all of the scenarios and variables examined (biomass, catch and NPV) as can be observed in Figure 2. It is clear that the parameters were important to the stock-recruitment Ricker's equation, particularly to the biomass, and this was true for all of the scenarios except for the open access condition. Under different management strategies, the introduction of variation $( \pm 20 \%)$ on the $q$ parameter, showed its effect over catch, which was greater in this variable than over others, such as biomass and NPV. Economic parameters like $P_{p s}$ and $U c$ generally showed more sensitivity to the NPV in all the scenarios (Fig. 2).

\section{Decision ANALYSES WITHOUT MATHEMATICAL PROBABILITIES}

The results of applying the Maximin criterion are shown in Table 1. Under conditions of variable $M$, the $\mathrm{f}_{2004}$ strategy provided the maximum value of the minimum $N P V$ and represented the strategy that would be most likely employed by an extremely cautious manager (with high risk-aversion). Under conditions

${ }^{1}$ DOF. 2012. Diario Oficial de la Federación. Ciudad de México, México, 24/Agosto/2012. <http://www.dof. gob. $\mathrm{mx}>$ 

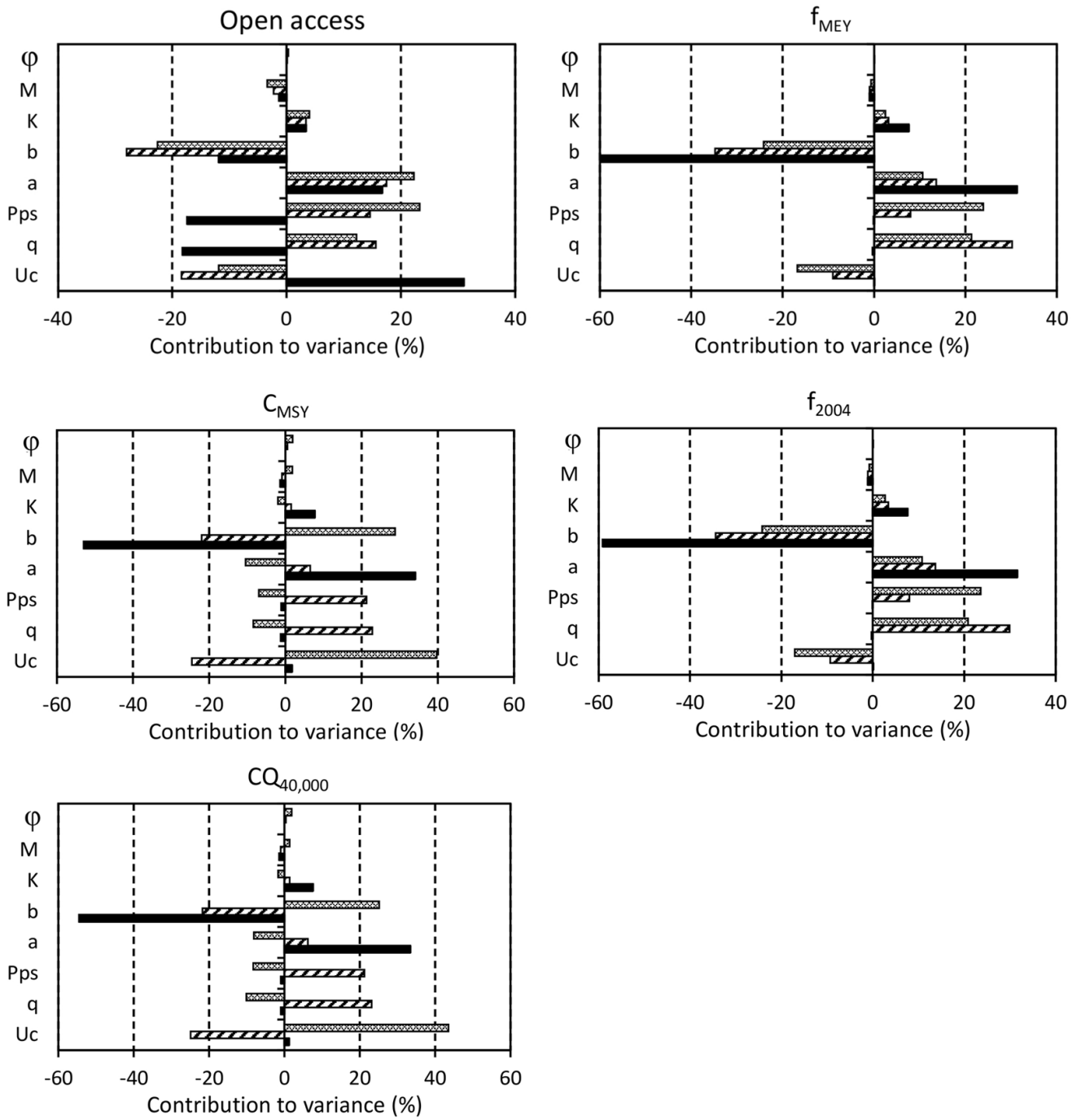

圆 NPV ■Catch $\square$ Biomass

Figure 2. Sensitivity analyses of 8 input parameters to the bioeconomic model evaluated for their effect on biomass, catch and NPV: unit cost of fishing effort (Uc), catchability coefficient $(q)$, average price for Pacific sardine $\left(P_{p s}\right)$, density-independent coefficient of the stockrecruitment Ricker's equation (a), density-dependent coefficient of the stock-recruitment Ricker's equation (b), growth coefficient of the von Bertalanffy's equation (K), natural mortality rate (M), and fleet dynamics parameter $(\varphi)$. The level of sensitivity is shown as contribution to the variance (\%) to the performance variables: biomass, catch, NPV, and to 5 management strategies / Los análisis de sensibilidad de los 8 parámetros de entrada al modelo bioeconómico evaluados por su efecto en la biomasa, captura y VPN: costo unitario del esfuerzo de pesca $(U c)$, coeficiente de capturabilidad $(q)$, precio promedio de la sardina del Pacífico $\left(P_{p s}\right)$, coeficiente denso-independiente de la ecuación stock-reclutamiento de Ricker (a), coeficiente denso-dependiente de la ecuación stock-reclutamiento de Ricker (b), coeficiente de crecimiento de la ecuación de von Bertalanffy (K), tasa de mortalidad natural (M), y el parámetro de dinámica de la flota $(\varphi)$. El nivel de sensibilidad se muestra como contribución a la varianza (\%) para las variables de desempeño: biomasa, captura, VPN, y para 5 estrategias de manejo 
Table 1. Results from the decision tables calculated without mathematical probabilities, using the Maximin criterion, and considering 5 management strategies with 9 states of nature (defined here as State 1 to State 9) accounting for changes in values of natural mortality (M), price $\left(\mathbf{P}_{\mathrm{ps}}\right)$, or catchability (q) / Resultados de las tablas de decisión calculadas sin probabilidades matemáticas, usando el criterio Maximin, y teniendo en cuenta 5 estrategias de manejo con 9 estados de la naturaleza (definidos aquí como Estado 1 a Estado 9) contabilizando los cambios en los valores de mortalidad natural $(M)$, precio $\left(P_{p s}\right)$, o capturabilidad $(q)$

\begin{tabular}{|c|c|c|c|c|}
\hline \multirow[b]{2}{*}{ Strategy } & \multicolumn{3}{|c|}{$N P V$ of the fishery (US dollars) } & \multirow[b]{2}{*}{$\begin{array}{c}\text { Minimum } \\
\text { value }\end{array}$} \\
\hline & $\begin{array}{c}\text { State 1 } \\
P_{p s}=\$ 52.6 \\
q=0.000155 \\
M=0.6\end{array}$ & $\begin{array}{c}\text { State } 2 \\
P_{p s}=\$ 52.6 \\
q=0.000155 \\
M=0.48\end{array}$ & $\begin{array}{c}\text { State 3 } \\
P_{p s}=\$ 52.6 \\
q=0.000155 \\
M=0.72\end{array}$ & \\
\hline Open access & 479,335 & 590,078 & 366,344 & 366,344 \\
\hline $\mathrm{f}_{\mathrm{MEY}}(756$ trips $)$ & 464,495 & 533,178 & 341,447 & 341,447 \\
\hline $\mathrm{C}_{\mathrm{MSY}}(45800$ ton $)$ & 84,466 & 76,911 & 86,193 & 76,911 \\
\hline $\mathbf{f}_{2004}$ (851 trips) & 497,564 & 574,133 & 419,307 & 419,307 \\
\hline \multirow[t]{3}{*}{$\mathrm{CQ}_{40,000}(40,000$ ton $)$} & 18,701 & 7,933 & 25,150 & 7,933 \\
\hline & \multicolumn{3}{|c|}{$N P V$ of the fishery (US dollars) } & \\
\hline & $\begin{array}{c}\text { State } 4 \\
M=0.6 \\
q=0.000155 \\
P_{p s}=\$ 52.6 \\
\end{array}$ & $\begin{array}{c}\text { State } 5 \\
M=0.6 \\
q=0.000155 \\
P_{p s}=\$ 42.08 \\
\end{array}$ & $\begin{array}{c}\text { State } 6 \\
M=0.6 \\
q=0.000155 \\
P_{p s}=\$ 63.12 \\
\end{array}$ & $\begin{array}{l}\text { Minimum } \\
\text { value }\end{array}$ \\
\hline Open access & 479,335 & $-11,790$ & 994,872 & $-11,790$ \\
\hline$f_{\mathrm{MEY}}(756$ trips $)$ & 464,495 & 72,039 & 795,178 & 72,039 \\
\hline $\mathrm{C}_{\mathrm{MSY}}$ (45800 ton) & 84,466 & $-83,562$ & 226,803 & $-83,4562$ \\
\hline $\mathrm{f}_{2004}(851$ trips $)$ & 497,564 & 62,667 & 936,413 & 62,667 \\
\hline \multirow[t]{3}{*}{$\mathrm{CQ}_{40,000}(40,000$ ton $)$} & 18,701 & $-126,207$ & 141,960 & $-126,207$ \\
\hline & \multicolumn{3}{|c|}{$N P V$ of the fishery (US dollars) } & \\
\hline & $\begin{array}{c}\text { State } 7 \\
M=0.6 \\
P_{p s}=\$ 52.6 \\
q=0.000155\end{array}$ & $\begin{array}{c}\text { State } 8 \\
M=0.6 \\
P_{p s}=\$ 52.6 \\
q=0.000124\end{array}$ & $\begin{array}{c}\text { State } 9 \\
M=0.6 \\
P_{p s}=\$ 52.6 \\
q=0.000186\end{array}$ & $\begin{array}{l}\text { Minimum } \\
\text { value }\end{array}$ \\
\hline Open access & 479,335 & 2,727 & 158,672 & 2,727 \\
\hline $\mathrm{f}_{\mathrm{MEY}}(756$ trips $)$ & 464,495 & 2,727 & 757,858 & 2,727 \\
\hline $\mathrm{C}_{\mathrm{MSY}}(45800$ ton $)$ & 84,466 & 2,727 & $-647,970$ & $-647,970$ \\
\hline $\mathrm{f}_{2004}(851$ trips $)$ & 497,564 & 2,727 & 888,062 & 2,727 \\
\hline $\mathrm{CQ}_{40,000}(40,000$ ton $)$ & 18,701 & 2,727 & $-722,063$ & $-722,063$ \\
\hline
\end{tabular}

Boldface indicates the selected management decision(s) according the Maximin criterion

in which price varies, a manager with risk-aversion would select the $f_{M E Y}$ strategy which defines a fishing effort on the range of 756 trips. Under conditions of variable $q$, assuming a value of $q=0.000124, \mathrm{NPV}$ values were low due to low catches in the model forecast.

The Minimax regret criterion would be applied when the manager is cautious, but not completely risk-averse. The best strategy for this type of manager, based on the results summarized in Table 2 is the $\mathrm{f}_{2004}$ strategy, as it resulted in the lowest regret for lost opportunities in all three cases.

The Maximax criterion would be applied by a resource manager who is broadly optimistic and risk-inclined. From the
Table 2. Results from the decision tables calculated without mathematical probabilities, using the M inimax regret criterion, and considering 5 management strategies with 9 states of nature (defined here as State 1 to State 9) accounting for changes in values of natural mortality (M), price $\left(\mathbf{P}_{\mathrm{ps}}\right)$ or catchability (q) / Resultados de las tablas de decisión calculadas sin probabilidades matemáticas, usando el criterio Minimax, y teniendo en cuenta 5 estrategias de manejo con 9 estados de la naturaleza (definidos aquí como Estado 1 a Estado 9) contabilizando los cambios en los valores de mortalidad natural $(M)$, precio $\left(P_{p s}\right)$, o capturabilidad (q)

\begin{tabular}{|c|c|c|c|c|}
\hline \multirow[b]{2}{*}{ Strategy } & \multicolumn{3}{|c|}{$N P V$ of the fishery (US dollars) } & \multirow[b]{2}{*}{$\underset{\text { regret }}{\text { Maximum }}$} \\
\hline & $\begin{array}{c}\text { State } 1 \\
P_{p s}=\$ 52.6 \\
q=0.000155 \\
M=0.6\end{array}$ & $\begin{array}{c}\text { State 2 } \\
P_{p s}=\$ 52.6 \\
q=0.000155 \\
M=0.48\end{array}$ & $\begin{array}{c}\text { State } 3 \\
P_{p s}=\$ 52.6 \\
q=0.000155 \\
M=0.72\end{array}$ & \\
\hline Open access & 18,229 & 0 & 52,963 & 52,963 \\
\hline $\mathrm{f}_{\mathrm{MEY}}(756$ trips $)$ & 33,069 & 56,899 & 77,860 & 77,860 \\
\hline $\mathrm{C}_{\mathrm{MSY}}(45800$ ton $)$ & 413,098 & 513,166 & 333,114 & 513,166 \\
\hline $\mathrm{f}_{2004}(851$ trips) & 0 & 15,944 & 0 & 15,944 \\
\hline \multirow[t]{3}{*}{$\mathrm{CQ}_{40,000}(40,000$ ton $)$} & 478,862 & 582,144 & 394,157 & 582,144 \\
\hline & \multicolumn{3}{|c|}{$N P V$ of the fishery (US dollars) } & \\
\hline & $\begin{array}{c}\text { State } 4 \\
M=0.6 \\
q=0.000155 \\
P_{p s}=\$ 52.6 \\
\end{array}$ & $\begin{array}{c}\text { State 5 } \\
M=0.6 \\
q=0.000155 \\
P_{p s}=\$ 42.08 \\
\end{array}$ & $\begin{array}{c}\text { State } 6 \\
M=0.6 \\
q=0.000155 \\
P_{p s}=\$ 63.12\end{array}$ & $\begin{array}{c}\text { Maximum } \\
\text { regret }\end{array}$ \\
\hline Open access & 18,229 & 83,829 & 0 & 83,829 \\
\hline $\mathrm{f}_{\mathrm{MEY}}(756$ trips $)$ & 33,069 & 0 & 199,694 & 199,694 \\
\hline $\mathrm{C}_{\mathrm{MSY}}(45800$ ton $)$ & 413,098 & 155,601 & 768,069 & 768,069 \\
\hline$f_{2004}(851$ trips $)$ & 0 & 9,372 & 58,459 & 58,459 \\
\hline \multirow[t]{3}{*}{$\mathrm{CQ}_{40,000}(40,000$ ton $)$} & 478,862 & 198,246 & 852,911 & 852,911 \\
\hline & \multicolumn{3}{|c|}{$N P V$ of the fishery (US dollars) } & \\
\hline & $\begin{array}{c}\text { State } 7 \\
M=0.6 \\
P_{p s}=\$ 52.6 \\
q=0.000155 \\
\end{array}$ & $\begin{array}{c}\text { State } 8 \\
M=0.6 \\
P_{p s}=\$ 52.6 \\
q=0.000124 \\
\end{array}$ & $\begin{array}{c}\text { State } 9 \\
M=0.6 \\
P_{p s}=\$ 52.6 \\
q=0.000186\end{array}$ & $\begin{array}{c}\text { Maximum } \\
\text { regret }\end{array}$ \\
\hline Open access & 18,229 & 0 & 729,389 & 729,389 \\
\hline $\mathrm{f}_{\mathrm{MEY}}(756$ trips $)$ & 33,069 & 0 & 130,204 & 130,204 \\
\hline $\mathrm{C}_{\mathrm{MSY}}(45800$ ton $)$ & 413,098 & 0 & $1,536,032$ & $1,536,032$ \\
\hline$f_{2004}(851$ trips $)$ & 0 & 0 & 0 & $\mathbf{0}$ \\
\hline $\mathrm{CQ}_{40,000}(40,000$ ton $)$ & 478,862 & 0 & $1,610,125$ & $1,610,125$ \\
\hline
\end{tabular}

Boldface indicates the selected management decision(s) according the Minimax criterion

data presented in Table 3 ( $M$ and $P_{p s}$, respectively), we can conclude that the simulated strategy most likely to produce the maximum-maximum NPV for the fishery would be the open access strategy. Under conditions of variable $q$, the maximummaximum NPV for the fishery would be the $\mathrm{f}_{2004}$ strategy.

Table 4 shows the results from the decision tables, using the Maximin, Minimax, and Maximax criteria, considering five management strategies over different assumptions accounting for changes in values of the discount rate $(\delta)$. The three criteria were observed to provide consistent results with those obtained previously, for example, that the best strategy for the sardine fishery is the effort applied in 2004 with 851 trips. Note also, that higher discount rate lowered the VPN. 
Table 3. Results from the decision tables calculated without mathematical probabilities, using the $M$ aximax criterion, and considering 5 management strategies with 9 states of nature (defined here as State 1 to State 9 ) accounting for changes in values of natural mortality $(\mathbf{M})$, price $\left(\mathbf{P}_{\mathrm{ps}}\right)$ or catchability $(\mathbf{q})$ / Resultados de las tablas de decisión calculadas sin probabilidades matemáticas, usando el criterio Maximax, y teniendo en cuenta 5 estrategias de manejo con 9 estados de la naturaleza (definidos aquí como Estado 1 a Estado 9) contabilizando los cambios en los valores de mortalidad natural $(M)$, precio $\left(P_{p s}\right)$, o capturabilidad $(q)$

\begin{tabular}{|c|c|c|c|c|}
\hline \multirow[b]{2}{*}{ Strategy } & \multicolumn{3}{|c|}{$N P V$ of the fishery (US dollars) } & \multirow[b]{2}{*}{ Maximum NPV } \\
\hline & $\begin{array}{c}\text { State 1 } \\
P_{p s}=\$ 52.6 \\
q=0.000155 \\
M=0.6\end{array}$ & $\begin{array}{c}\text { State 2 } \\
P_{p s}=\$ 52.6 \\
q=0.000155 \\
M=0.48\end{array}$ & $\begin{array}{c}\text { State 3 } \\
P_{p s}=\$ 52.6 \\
q=0.000155 \\
M=0.72\end{array}$ & \\
\hline Open access & 479,335 & 590,078 & 366,344 & 590,078 \\
\hline $\mathrm{f}_{\mathrm{MEY}}(756$ trips $)$ & 464,495 & 533,178 & 341,447 & 533,178 \\
\hline $\mathrm{C}_{\mathrm{MSY}}(45800$ ton $)$ & 84,466 & 76,911 & 86,193 & 86,193 \\
\hline $\mathrm{f}_{2004}(851$ trips $)$ & 497,564 & 574,133 & 419,307 & 574,133 \\
\hline \multirow[t]{3}{*}{$\mathrm{CQ}_{40,000}(40,000$ ton $)$} & 18,701 & 7,933 & 25,150 & 25,150 \\
\hline & \multicolumn{3}{|c|}{$N P V$ of the fishery (US dollars) } & \multirow[b]{2}{*}{ Maximum NPV } \\
\hline & $\begin{array}{c}\text { State } 4 \\
M=0.6 \\
q=0.000155 \\
P_{p s}=\$ 52.6\end{array}$ & $\begin{array}{c}\text { State 5 } \\
M=0.6 \\
q=0.000155 \\
P_{p s}=\$ 42.08\end{array}$ & $\begin{array}{c}\text { State } 6 \\
M=0.6 \\
q=0.000155 \\
P_{p s}=\$ 63.12\end{array}$ & \\
\hline Open access & 479,335 & $-11,790$ & 994,872 & 994,872 \\
\hline $\mathrm{f}_{\mathrm{MEY}}(756$ trips $)$ & 464,495 & 72,039 & 795,178 & 795,178 \\
\hline $\mathrm{C}_{\mathrm{MSY}}(45800$ ton $)$ & 84,466 & $-83,562$ & 226,803 & 226,803 \\
\hline $\mathrm{f}_{2004}(851$ trips $)$ & 497,564 & 62,667 & 936,413 & 936,413 \\
\hline $\mathrm{CQ}_{40,000}(40,000$ ton $)$ & 18,701 & $-126,207$ & 141,960 & 141,960 \\
\hline \multirow[b]{2}{*}{ Strategy } & \multicolumn{3}{|c|}{$N P V$ of the fishery (US dollars) } & \\
\hline & $\begin{array}{c}\text { State } 7 \\
M=0.6 \\
P_{p s}=\$ 52.6 \\
q=0.000155\end{array}$ & $\begin{array}{c}\text { State } 8 \\
M=0.6 \\
P_{p s}=\$ 52.6 \\
q=0.000124\end{array}$ & $\begin{array}{c}\text { State } 9 \\
M=0.6 \\
P_{p s}=\$ 52.6 \\
q=0.000186\end{array}$ & Maximum NPV \\
\hline Open access & 479,335 & 2,727 & 158,672 & 479,335 \\
\hline $\mathrm{f}_{\mathrm{MEY}}(756$ trips $)$ & 464,495 & 2,727 & 757,858 & 757,858 \\
\hline $\mathrm{C}_{\mathrm{MSY}}(45800$ ton $)$ & 84,466 & 2,727 & $-647,970$ & 84,466 \\
\hline$f_{2004}$ (851 trips) & 497,564 & 2,727 & 888,062 & 888,062 \\
\hline $\mathrm{CQ}_{40,000}(40,000$ ton $)$ & 18,701 & 2,727 & $-722,063$ & 18,701 \\
\hline
\end{tabular}

Boldface indicates the selected management decision(s) according the Maximax criterion
Table 4. Results from the decision tables calculated without mathematical probabilities, using the Maximin, Minimax and Maximax critera, and considering 5 management strategies under 3 states of nature (defined here as State $10, \delta=0.04$; State $11, \delta=0.02$; State 12 , $\delta=0.06)$. It was considered changes in values of the discount rate $(\delta)$; all other parameters were assumed as constant / Resultados de las tablas de decisión calculadas sin probabilidades matemáticas, usando los criterios Maximin, Minimax y Maximax, y teniendo en cuenta 5 estrategias de manejo con 3 estados de la naturaleza (definidos aquí como Estado 10, $\delta=0,04$; Estado 11, $\delta=0,02$; Estado $12, \delta=0,06)$ contabilizando los cambios en los valores de la tasa de descuento $(\delta)$; todos los parámetros se asumen constantes

\begin{tabular}{|c|c|c|c|c|}
\hline \multirow{2}{*}{$\begin{array}{l}\text { Maximin criterion } \\
\text { Strategy }\end{array}$} & \multicolumn{3}{|c|}{$N P V$ of the fishery (US dollars) } & \multirow{2}{*}{$\begin{array}{l}\text { Minimum } \\
\text { value }\end{array}$} \\
\hline & $\begin{array}{l}\text { State 10 } \\
\delta=0.04\end{array}$ & $\begin{array}{l}\text { State 11 } \\
\delta=0.02\end{array}$ & $\begin{array}{l}\text { State 12 } \\
\delta=0.06\end{array}$ & \\
\hline Open access & 479,335 & $1,619,074$ & 145,924 & 145,924 \\
\hline $\mathrm{f}_{\mathrm{MEY}}$ (756 trips) & 464,495 & $1,591,072$ & 139,545 & 139,545 \\
\hline $\mathrm{C}_{\mathrm{MSY}}(45800$ ton $)$ & 84,466 & 264,605 & 27,575 & 27,575 \\
\hline$f_{2004}(851$ trips $)$ & 497,564 & $1,705,182$ & 149,398 & 149,398 \\
\hline $\mathrm{CQ}_{40,000}(40,000$ ton $)$ & 18,701 & 55,657 & 6,394 & 6,394 \\
\hline Minimax criterion & \multicolumn{3}{|c|}{$N P V$ of the fishery (US dollars) } & \multirow[b]{2}{*}{$\begin{array}{c}\text { Maximum } \\
\text { regret }\end{array}$} \\
\hline Strategy & $\begin{array}{l}\text { State } 10 \\
\delta=0.04\end{array}$ & $\begin{array}{l}\text { State 11 } \\
\delta=0.02\end{array}$ & $\begin{array}{l}\text { State } 12 \\
\delta=0.06\end{array}$ & \\
\hline Open access & 18,229 & 86,108 & 3,474 & 86,108 \\
\hline $\mathrm{f}_{\mathrm{MEY}}$ (756 trips) & 33,069 & 114,109 & 9,853 & 114,109 \\
\hline $\mathrm{C}_{\mathrm{MSY}}(45800$ ton $)$ & 413,098 & $1,440,577$ & 121,823 & $1,440,577$ \\
\hline$f_{2004}$ (851 trips) & 0 & 0 & 0 & $\mathbf{0}$ \\
\hline $\mathrm{CQ}_{40,000}(40,000$ ton $)$ & 478,862 & $1,649,524$ & 143,004 & $1,649,524$ \\
\hline Maximax criterion & \multicolumn{3}{|c|}{$N P V$ of the fishery (US dollars) } & \\
\hline Strategy & $\begin{array}{l}\text { State } 10 \\
\delta=0.04\end{array}$ & $\begin{array}{l}\text { State } 11 \\
\delta=0.02 \\
\end{array}$ & $\begin{array}{l}\text { State 12 } \\
\delta=0.06\end{array}$ & NPV \\
\hline Open access & 479,335 & $1,619,074$ & 145,924 & $1,619,074$ \\
\hline $\mathrm{f}_{\mathrm{MEY}}(756$ trips $)$ & 464,495 & $1,591,072$ & 139,545 & $1,591,072$ \\
\hline $\mathrm{C}_{\mathrm{MSY}}(45800$ ton $)$ & 84,466 & 264,605 & 27,575 & 264,605 \\
\hline$f_{2004}$ (851 trips) & 497,564 & $1,705,182$ & 149,398 & $1,705,182$ \\
\hline $\mathrm{CQ}_{40,000}(40,000$ ton $)$ & 18,701 & 55,657 & 6,394 & 55,657 \\
\hline
\end{tabular}

Boldface indicates the selected management decision(s) according the criterion

Table 5. Probabilities of exceeding the values used as Limit Reference Points (LRPs) and Target Reference Points (TRPs) for the biomass, catch and Net Present Value (NPV) for each of the different simulated strategies in 2017. Uncertainty is incorporated into 7 parameters, growth coefficient (K), density-independent coefficient (a), density-dependent coefficient (b), natural mortality (M), catchability coefficient (q), price for target species ( $\left.P_{p s}\right)$ and unit cost of fishing effort (Uc). Probabilities were determined across the 10,000 simulations / Probabilidades de exceder los valores usados como Puntos de Referencia Límite (PRL) y Puntos de Referencia Objetivo (PRO) para la biomasa, captura y Valor Presente Neto (VPN) para cada una de las diferentes estrategias simuladas en el 2017. La incertidumbre es incorporada en 7 parámetros, coeficiente de crecimiento (K), coeficiente denso-independiente (a), coeficiente denso-dependiente (b), mortalidad natural (M), coeficiente de capturabilidad (q), precio de la especie objetivo $\left(P_{p s}\right)$ y el costo unitario del esfuerzo de pesca $(U C)$. Las probabilidades se determinaron a partir de 10.000 simulaciones

\begin{tabular}{lcccccc}
\hline & \multicolumn{2}{c}{ Biomass (ton) } & \multicolumn{2}{c}{ Catch (ton) } & \multicolumn{2}{c}{$\begin{array}{c}\text { NPV } \\
\text { (US dollars) }\end{array}$} \\
\cline { 2 - 7 } Strategy & LRP & TRP & LRP & TRP & LRP & TRP \\
\cline { 2 - 7 } & B $_{\text {MSY }}$ & B $_{\text {MEY }}$ & C $_{\text {MSY }}$ & C $_{2 / 3 M S Y}$ & BE & MEY \\
& 274,741 & 375,035 & 45,800 & 30,533 & 0 & 112,298 \\
\hline \multirow{2}{*}{ Open Access } & 51.5 & 0.0 & 60.1 & 34.7 & 13.6 & 0.0 \\
$\mathbf{f}_{\text {MEY }}$ & $\mathbf{6 . 3}$ & 0.0 & $\mathbf{0 . 0}$ & 48.5 & $\mathbf{3 . 3}$ & 0.0 \\
C $_{\text {MSY }}$ & 19.9 & 0.0 & - & 34.7 & 29.2 & 0.0 \\
$\mathbf{f}_{\text {2004 }}$ & $\mathbf{7 . 3}$ & 0.0 & $\mathbf{0 . 2}$ & 23.1 & $\mathbf{3 . 4}$ & 0.0 \\
CQ $_{40,000}$ & 15.5 & 0.0 & - & 35.0 & 34.7 & 0.0 \\
\hline
\end{tabular}

Probabilities expressed in percent; $\mathrm{BE}$ is the bioeconomic equilibrium point

Boldface indicates the selected management decision(s) according the acceptable risk (below $10 \%$ ) 


\section{Monte Carlo analyses and probabilities of EXCEEDING THE LRPS AND TRPS}

The probabilities of exceeding LRPs and TRPs are shown in Table 5. LRPs and TRPs for biomass, catch and NPV were evaluated to predict their values for year 2017. The $f_{M E Y}$ and $\mathrm{f}_{2004}$ strategies result in lower probabilities of exceeding LRPs, and open access which showed high probabilities of exceeding LRPs. In the case of biomass and NPV the probability of exceeding TRPs for all strategies was equal to zero. In general, the $f_{M E Y}$ and $f_{2004}$ management strategies had the lowest probabilities for producing undesirable levels of biomass, catch and NPV (Table 5).

\section{Discussion}

In this study, the developed formal decision-making model aimed to quantify the effect of alternative management strategies over several state variables of the sardine fishery, including the economic value, within a precautionary approach to fishery management. The proposed dynamic bioeconomic model was built to incorporate, in a simple way, biological, environmental, and economic factors related to the Pacific sardine fishery off the western coast of the Baja California peninsula. The Maximin and Minimax criteria that were considered for making fishery management decisions suggest that strategies employed to regulate the fishing effort $\left(\mathrm{f}_{2004}\right.$ and $\mathrm{f}_{\mathrm{MEY}}$ ) will result in the best outcome for the sardine fishery; that is, the economic gains from this fishery could be increased by changes in effort regulations. The Monte Carlo-based simulation analyses also indicate that strategies involving the control of fishing effort can result in lower probabilities of exceeding LRPs, even when there is uncertainty in parameters such as $U c, q, P_{p s}, a, b, K$ and $M$ occur, suggesting that these types of strategies represent the most viable options for the management of the sardine fishery under study.

Current management strategies that are applicable to the sardine fishery are defined by the Mexican Official Norm NOM-003-PESC-1993 (DOF 1993) ${ }^{2}$, which establishes minimum legal catch size of $150 \mathrm{~mm}$ of standard length (SL) for the entire Pacific Ocean including the Gulf of California. The entry of new fishing permits (effort control) to the fishery is limited depending on the storage capacity of the vessels, the maximum size of purse seines is limited, and an exploitation rate of 0.25 has been recommended; it also establishes the possibility of applying bans associated with the reproductive period of the sardine. The catch of sardine with size less than $150 \mathrm{~mm}$ SL should not exceed $30 \%$ in number of individuals landed per season. In addition, since 1993 and up to date, in the Gulf of California there have been suspensions per unit area of fishing or total closure during August and September in order to protect juveniles (DOF $2004^{3}$; DOF $2012^{1}$ ). It is apparent that management for sardine includes input control and output control, however, measures such as those proposed in this study that involve controlling the fishing effort in number of trips ( $f_{\mathrm{MEY}}$ and $f_{2004}$ with 756 and 851 trips, respectively), has not yet been suggested. An administrative measure of this nature could operate with a higher profit margin without over-exploiting the sardine resource. Nonetheless, it involves a series of adaptations and flexible conditions to enforce controls in fishing effort, assuming availability of updated information that accounts for uncertain conditions, which could impact the resource and, thus, the parameters of the fishery. It is also important to control the fishing capacity of the fleet in order to maintain the sustainability of the fishery and avoid rent dissipation over time.

Given that the sensitivity analysis used to evaluate the performance of the model showed that $U c, q, P_{p s}, a, b, K, M$ and $\varphi$ were sensitive over biomass, catch and NPV; hence, all parameters except the fleet dynamics parameter $(\varphi)$ were used for testing alternative management scenarios for the sardine fishery. All parameters can have an additive or multiplicative effect, hence an error in estimating their value can affect the performance of the model and consequently, the decisionmaking processes that depends on the results from these models.

The results of this study highlight the importance of economic factors in regulating the dynamics of fishery fleets to control fishing activities. This does not dismiss the relevance of other variables; for instance, interactions between the effective fishing effort and the natural resource that is being targeted are measured by $q$. Variation in this parameter is relevant because it has an inverse exponential relationship with stock abundance, being more highly impacted by the amount of fishing when stock size is lower (Martínez-Aguilar et al. 2009). Although a monotonically decreasing function with the size of the population was not incorporated in the mathematical model, the results of the deterministic (Maximin, Minimax, and Maximax criteria) and stochastic approaches (probabilities of exceeding the values used as LRPs and TRPs for the biomass, catch and NPV) are consistent when the management strategy fixed the effort equivalent of $\mathrm{f}_{2004}$, consistent with the most advisable strategy for the sardine fishery. We believe that if the density-dependent function on catchability was incorporated, considering the effect of increasing improvements in technology, we would expect a reduction in the time to reach the TRPs.

${ }^{3}$ DOF 2004. Diario Oficial de la Federación. Ciudad de México, México, 15/03/2004. <http://www.dof.gob.mx>
${ }^{2}$ DOF 1993. Diario Oficial de la Federación. Ciudad de México, México, 31/12/1993. <http://www.dof.gob.mx> 
Values of $P_{p s}, q$, and $U c$ are also influenced by several other factors, including the availability and abundance of stocks, economic demand, and environmental conditions. Improvement on stock assessment also requires robust estimates of $M$, which are generally difficult to obtain for most populations as mortality may vary spatially, temporally, or in relation to size/age of fish due to many biotic and abiotic factors. For this reason, the conventional practice in fishery stock assessment had assumed the value of this parameter as constant for fully-recruited individuals (Caddy 1991, Martínez-Aguilar et al. 2005). In this regard, one way to go around these limitations is to test the effect of potential changes on several state variables, given potential changes in this parameter incorporated in the bioeconomic model based on the precautionary approach. Results in this study showed that natural mortality is not one of the main drivers of uncertainty over the state variables (Fig. 2), despite how sensitive the sardine is to environmental factors that can affect recruitment. This is also reflected on the decision tables (Tables 1, 2 and 3), when changes in values of natural mortality resulted in the lowest effects over NPV.

Decision making analyses without mathematical probabilities, which use the Maximin, Minimax and Maximax criteria that represent managers with high risk-aversion, not totally riskaverse and risk-inclined, respectively, resulted in selection of the $\mathrm{f}_{2004}, \mathrm{f}_{\mathrm{MEY}}$, and open access strategies, respectively. A highly cautious manager, represented by the Maximin criterion, would select either the $\mathrm{f}_{2004}$ or $\mathrm{f}_{\mathrm{MEY}}$ strategy under conditions where either $M, P_{p s}$ or $q$ could vary. When the manager is cautious, but not completely risk-averse (Minimax criterion) the same $\mathrm{f}_{2004}$ strategy was chosen irrespective of either $M, P_{p s}$ or $q$ vary. A resource manager who is broadly optimistic and risk-inclined (Maximax criterion), the open access and $\mathrm{f}_{2004}$ strategies were chosen depending on either $M, P_{p s}$ or $q$ vary.

The results from these analyses show that management strategies chosen by a particular manager will vary according to their personal preferences at that time, the information at hand and the legislation in place, which can restrict or facilitate the implementation of the selected strategy. The advantage of incorporating risk and uncertainty in fisheries assessment is that decision makers in charge of management can have an idea of the potential effect of such decisions (Anderson \& Seijo 2010, d'Eon-Eggertson et al. 2015). As stated by Uusitalo et al. (2015) the quality of the information available and the type of models and approaches used define the level of analysis incorporating uncertainty, in this regard decision tables and Monte Carlo simulation offer a friendly tool to provide advice to fisheries managers.
The fishing effort during the last 5 years in this analysis $(>800$ fishing days) was observed to be slightly higher than the fishing effort under the $\mathrm{f}_{\mathrm{MEY}}$ strategy (756 trips), which could be indicative of a fishery in 'reasonably good conditions', since it shows that the fishery could maintain an acceptable income level under an open access regime without triggering signals of overfishing in the analyzed period (1983-2004), even if the maximum revenues are not attained. The management strategy that could provide the best fit in this simulation model irrespective of risk tolerance levels was determined to be the $\mathrm{f}_{2004}$ strategy with 851 trips, value closer to the fishing effort of the 20002004 period. However, stock size oscillations that may result from environmental fluctuations should also be taken into account when deciding on a particular management strategy. For instance, De Anda-Montañez et al. (2010) analyzed uncertainty by defining four states of nature associated with environmental variability as represented by the multivariate ENSO index (MEI) (El Niño Southern Oscillation, ENSO); state 1: run base (values of MEI near to zero; state 2: positive values of MEI (El Niño conditions); state 3: negative values of MEI(La Niña conditions); and state 4: cycle El Niño-La Niña. The results showed that, when the MEI value was positive (equivalent to conditions of an El Niño event), a negative effect on the fishery was observed. When this environmental variability was taken into account, the results of the decision analysis with mathematical probabilities indicated that the selected management strategies vary according to the decision criterion, i.e. a risk-neutral decision maker selected the $\mathrm{f}_{2004}$ strategy, a risk-averse fishery manager selected the catch-quota strategy, and an administrator willing to take a risk selected the open-access strategy. Use of the Bayesian criterion indicated that the manager selected the strategy of $\mathrm{f}_{2004}$. The decision analysis without mathematical probabilities, which use the three criteria (Maximin, Minimax and Maximax), indicated that the selected management strategies also vary according to the criterion, i.e. a risk-aversion administrator (Maximin criterion) selected the $\mathrm{f}_{\mathrm{MEY}}$ strategy, a less cautious administrator (Minimax criterion) selected $\mathrm{f}_{2004}$ strategy, and a broadly optimistic administrator (Maximax criterion) selected the open access strategy. In the present study, the results of the decision analysis without mathematical probabilities accounting for changes in values of $M, P_{p s}$ or $q$ were more consistent with those obtained by De Anda-Montañez et al. (2010), i.e., the most frequently chosen strategy was $\mathrm{f}_{2004}$.

The Monte Carlo analysis also showed the strategies that incorporate the fishing effort limitations as the most viable for the sardine fishery ( $\mathrm{f}_{\mathrm{MEY}}$ and $\mathrm{f}_{2004}$ ), with the lower probabilities of exceeding the LRP for biomass, catch and NPV, i.e., with an acceptable risk, which was defined in this study below $10 \%$. In general, these strategies seem to result in better outcomes 
than the open access, $\mathrm{CQ}_{40,000}$ and $\mathrm{C}_{\mathrm{MSY}}$ strategies, that represent scenarios in which a substantial increase in effort is necessary to obtain the highest possible fishery yield. Grafton et al. (2007) reported that, in practice, the biomass associated with maximization of discounted profits (maximize NPV) is higher than that related to MSY. This suggests that the use of reference points lower than $\mathrm{f}_{\mathrm{MSY}}$ may be a win-win strategy, higher profits and safer biomass (Grafton et al. 2007, Da Rocha et al. 2012).

Results from this study suggest that additional efforts to control overfishing (fishing mortality rate above the level that provides for the level of MSY), such as robust estimates of biomass, regulation of the type and size of the crafts, seasonal closures, among others, are needed for this type of resource. The call for a combination of management regulations (redundant management or portfolio management) is increasing among fisheries scientists (Wilen 2000, Hilborn 2003, Seijo et al. 2004, Hilborn 2010). The best outcomes for fishery management will likely result from applying a combination of strategies.

While the results from this study suggest that strategies incorporating the regulation of fishing efforts may contribute to maintain the sardine fishery, yields cannot be maintained in the long term without incorporating additional regulatory mechanisms into the management of this fishery as stated earlier. For instance, the Pacific sardine off the western coast of the Baja California peninsula, includes among its management regulations a minimum legal size of capture of $160 \mathrm{~mm}$ standard length (DOF 2010 $)$, which is a tool oriented to reduce fishing mortality. Seasonal closures could also help to maintain sardine production at a sufficient level to maintain the stock. However, effort management has been regarded as a more effective measure by different authors (Kraak et al. 2008, Ulrich et al. 2011).

A key characteristic of sardine stocks is their interannual variation that, in some cases, increases by several orders of magnitude in biomass. Such variations in biomass or events such as the migrations from fishing grounds that have been reported by some authors (Félix-Uraga et al. 1996, 2004) can impact the fishery and the decision-making process related to its management. Assuming that such variations in biomass have an impact on market prices, the results of the open access strategy simulated here could result in decreased biomass, ultimately causing the fishery to be unstable in the long term. The migration is another factor in this analysis that could at least affect the

${ }^{4}$ DOF. 2010. Carta Nacional Pesquera. Costa Pacífico. Diario Oficial de la Federación. Segunda Sección. Secretaría de Agricultura, Ganadería, Desarrollo Rural, Pesca y Alimentación, México. 2 de Diciembre de 2010, 318 pp. fleet dynamics (fishing effort to revenue) relationship assumed in this study. Thus, it is recommended in future studies to incorporate uncertainty in the migration of sardines.

The results of this study cannot be directly considered for management purposes for Pacific sardine fishery, since both the bioeconomic model and the fisheries data need to be updated; however, they illustrate the importance of implementing this type of dynamic model, which takes into account some sources of uncertainty and risk in fisheries. It is recommended for the sardine fishery off the southwest coast of the Baja California peninsula to make the necessary assessments to develop a more accurate combination of TRPs and LRPs prior to their adoption into the fishery management. These reference points should be clearly defined and must have been agreed in advance, so that they can be executed without negotiation as suggested by Caddy \& Mahon (1995).

It is important to stress that well-informed managers and fishermen can make decisions in their own interest and contribute to reach societal goals when they learn about the impact of different fisheries policies under different contexts. The usefulness of bioeconomic models that integrate risk analysis offer an opportunity to portray results to stakeholders in order to seek successful fisheries management, better science that integrates complexity of the fisheries and uncertainty in the analyses, can generate better governance systems.

\section{ACKNOWLEDGMENTS}

Authors thank sardine fishing producers from the ports of San Carlos and Adolfo López Mateos, Baja California Sur, México, for supplying data about the Pacific sardine fishery in Magdalena Bay. Authors also thank Willow G. (American Journal Experts) and T. Zenteno-Savín for editing the English-language text. JAAM thanks financial support through CONACYT (Grant 19371).

\section{LITERATURE CITED}

Álvarez-Diaz M \& M Dominguez-Torreiro. 2006. Using genetic algorithms to estimate and validate bioeconomic models: The case of the Ibero-atlantic sardine fishery. Journal of Bioeconomics 8(1): 55-65.

Anderson LG \& JC Seijo. 2010. Bioeconomics of fisheries management, 305 pp. John Wiley \& Sons, Singapore.

Baranov FI. 1918. On the question of the biological basis of fisheries. Izvestiya Nauchno-Issled Institut 1: 81-128.

Caddy FJ. 1991. Death rates and time intervals: is there an alternative to the constant natural mortality axiom? Reviews in Fish Biology and Fisheries 1: 109-138. 
Caddy JF \& R Mahon. 1995. Reference points for fishery management. FAO Fisheries Technical Paper 347: 1-83.

Cisneros-Mata MA, MO Nevárez-Martínez \& MG Hammann. 1995. The rise and fall of the Pacific sardine, Sardinops sagax caeruleus Girard, in the Gulf of California, Mexico. California Cooperative Oceanic Fisheries Investigations Report 36: 136-143.

Clark CW. 1990. Mathematical bioeconomics: The optimal management of renewable resources, $400 \mathrm{pp}$. John Wiley and Sons, New York.

d'Eon-Eggertson F, NK Dulvy \& R Peterman. 2015. Reliable Identification of Declining Populations in an Uncertain World. Conservation Letters 8(2): 86-96.

Da Rocha JM, MJ Gutiérrez \& S Cerviño. 2012. Reference points based on dynamic optimization: a versatile algorithm for mixed-fishery management with bioeconomic agestructured models. ICES Journal of Marine Science 69(4): 660-669.

De Anda-Montañez A \& JC Seijo. 1999. Bioeconomics of the Pacific sardine (Sardinops sagax) fishery in the Gulf of California, México. California Cooperative Oceanic Fisheries Investigations Report 40: 170-178.

De Anda-Montañez JA, A Ramos-Rodríguez \& S MartínezAguilar. 2010. Effects of environmental variability on recruitment and bioeconomic modelling in the Pacific sardine (Sardinops sagax caerulea) fishery from Magdalena Bay, Baja California Sur, Mexico. Scientia Marina 74(1): 25-35.

Félix-Uraga R. 1990. Crecimiento de Sardinops sagax caerulea en Bahía Magdalena, México. Investigaciones Marinas 5(1): 27-31.

Félix-Uraga R. 1992. Composición por edades de la sardina monterrey Sardinops caeruleus capturadas en Bahía Magdalena, B.C.S., México, de 1981 a 1991. Investigaciones Marinas 7(1): 9-13.

Félix-Uraga R, RM Alvarado-Castillo \& R Carmona-Piña. 1996. The sardine fishery along the western coast of Baja California, 1981 to 1994. California Cooperative Oceanic Fisheries Investigations Report 37: 188-193.

Félix-Uraga R, VM Gómez-Muñoz, C QuiñonesVelázquez, FN Melo-Barrera \& W García-Franco. 2004. On the existence of pacific sardine groups off the west coast of Baja California and southern California. California Cooperative Oceanic Fisheries Investigations Report 45: 146151.

Galindo-Cortés G, JA De Anda-Montañez, F ArreguínSánchez, S Salas \& EF Balart. 2010. How do environmental factors affect the stock-recruitment relationship? The case of the Pacific sardine (Sardinops sagax) of the northeastern Pacific Ocean. Fisheries Research. 102: 173-183.

Grafton RQ, T Kompas \& RW Hilborn. 2007. Economics of overexploitation revisited. Science 318: 1601.
Hilborn R \& CJ Walters. 1992. Quantitative fisheries stock assessment: choice, dynamics and uncertainty, 570 pp. Chapman and Hall, New York.

Hilborn R. 2003. The state of the art in stock assessment: where we are and where we are going. Scientia Marina 67 (Suppl. 1): 15-20.

Hilborn R. 2010. Pretty Good Yield and exploited fishes. Marine Policy 34: 193-196.

Ivar SS. 2010. A conceptional analysis of dynamics and production in bioeconomic models. American Journal of Agricultural Economics 93(3): 803-812.

Jiao Y, D Schneider, Y Chen \& J Wroblewski. 2004. An analysis of error structure in modeling the stock-recruitment data of gadoid stocks using generalized linear models. Canadian Journal of Fisheries and Aquatic Sciences 61: 134146.

Kraak SBM, FC Buisman, M Dickey-Collas, JJ Poos, MA Pastoors, JGP Smith, JAE Oostenbrugge \& N Daan. 2008. The effect of management choices on the sustainability and economic performance of a mixed fishery: a simulation study. ICES Journal of Marine Science 65: 697-712.

Larkin PA. 1977. An epitaph for the concept of maximum sustainable yield. Transactions of the American Fisheries Society 106: 1-11.

Martínez-Aguilar S, F Arreguín-Sánchez \& E MoralesBojórquez. 2005. Natural mortality and life history stage duration of Pacific sardine (Sardinops caeruleus) based on gnomonic time divisions. Fisheries Research 71: 103-114.

Martínez-Aguilar S. 2006. Dynamics model of the Pacific sardine fishery (Sardinops caeruleus) from Gulf of California, Mexico. Tesis Doctoral, Centro Interdisciplinario de Ciencias Marinas, Instituto Politécnico Nacional, La Paz, $171 \mathrm{pp}$.

Martínez-Aguilar S, JA De Anda-Montañez, F ArreguínSánchez \& MA Cisneros-Mata. 2009. Constant harvest rate for the Pacific sardine (Sardinops caeruleus) fishery in the Gulf of California based on catchability-at-length estimations. Fisheries Research 99: 74-82.

Massey DM, SC Newbold \& B Gentner. 2006. Valuing water quality changes using a bioeconomic model of a coastal recreational fishery. Journal of Environmental Economics and Management 52(1): 482-500.

Morales-Bojórquez E, VM Gómez-Muñoz, R Félix-Uraga \& RM Alvarado-Castillo. 2003. Relation between recruitment; sea surface temperature, and dependent-density mortality of the Pacific sardine (Sardinops caeruleus) off the southwest coast of the Baja California Peninsula, Mexico. Scientia Marina 67(1): 25-32.

Morales-Bojórquez E. 1999. Analysis of the process and observation error in recruitment estimates for the Pacific sardine, Sardinops sagax caeruleus (Girard), off the southwest coast of the Baja California peninsula, Mexico. Ciencias Marinas 25(4): 597-608. 
Morales-Bojórquez E. 2002. Bayes theorem applied to the yield estimate of the Pacific sardine (Sardinops sagax coeruleus Girard) from Bahia Magdalena, Baja California Sur, Mexico. Ciencias Marinas 28(2): 167-179.

Mullon C, J-F Mittaine, O Thébaud, G Péron, G Merino \& M Barenge. 2009. Modeling the global fishmeal and fish oil markets. Natural Resource Modeling 22(4): 564-609.

Pennington M. 1996. Estimating the mean and variance from highly skewed marine data. Fishery Bulletin 94: 498-505.

Pintassilgo P \& CC Duarte. 2002. Optimal management of Northern Atlantic Bluefin tuna. Marine Resource Economics 17(1):47-67.

Politikos DV, CD Maravelias \& DE Tzanetis. 2013. Assessing the risk of alternative management strategies in a Mediterranean fishery: protecting the younger vs reducing fishing effort. Journal of Biological Dynamics 7(1): 183-198.

Prellezo R, P Accadia, JL Anderson, A Little, R Nielsen, BS Anderson, C Röckmann, J Powell \& E Buisman. 2009. Survey of existing bioeconomic models: Final report, 283 pp. AZTI-Tecnalia, Sukarrieta.

Ricker WE. 1975. Computation and interpretation of biological statistics of fish populations. Bulletin of the Fisheries Research Board of Canada 191: 1-382.

Seijo JC \& JF Caddy. 2008. Port location for inshore fleets affects the sustainability of coastal source-sink resources: Implications for spatial management of metapopulations. Fisheries Research 91: 336-348.

Seijo JC, E Pérez, M Cabrera \& D Hernández. 1997a. Riesgo e incertidumbre en el manejo de recursos vivos: un enfoque bioeconómico precautorio. En: Taller de Gestión de Sistemas Oceanográficos del Pacífico Oriental, Comisión Oceanográfica Intergubernamental de la UNESCO. IOC/ INF-1046, Universidad de Concepción, Chile, 9-16 de abril 1996, 432 pp.

Seijo JC, O Defeo \& S Salas. 1997b. Bioeconomía pesquera. Teoría, modelación y manejo. FAO Documento Técnico de Pesca 368: 1-176.
Seijo JC, EP Pérez \& JF Caddy. 2004. A simple approach for dealing with dynamics and uncertainty in fisheries with heterogeneous resource and effort distribution. Marine and Freshwater Research 55: 249-256.

Silvestri S \& F Maynou. 2009. Application of a bioeconomic model for supporting the management process of the small pelagic fishery in the Veneto region, northern Adriatic Sea, Italy. Scientia Marina 73(3): 563-572.

Smith MD \& JE Wilen. 2003. Economic impacts of marine reserves: the importance of spatial behavior. Journal of Environmental Economics and Management 46(2): 183-206.

Smith MD, J Zhang \& FC Coleman. 2008. Econometric modeling of fisheries with complex life histories: avoiding biological management failures. Journal of Environmental Economics and Management 55(3): 265-280.

Smith VL. 1969. On models of commercial fisheries. Journal of Political Economy 77: 181-198.

Tahvonen O. 2008. Harvesting age-structured populations as a biomass: Does it work? Natural Resource Modelling 21: 525-550.

Tahvonen O. 2010. Age structured optimization models in fisheries bioeconomics: a survey. In: Boucekkine R, N Hritonenko \& Y Yatsenko (eds). Optimal control of agestructured populations in economy demography, and the environment. Series Environmental Economics, pp 140-173. Routledge, London.

Ulrich C, SA Reeves, Y Vermard, SJ Holmes \& W Vanhee. 2011. Reconciling single-species TACs in the North Sea demersal fisheries using the Fcube mixed-fisheries advice framework. ICES Journal of Marine Science 68: 1535-1547.

Uusitalo L, A Lehikoinen, I Helle \& K Myrberg. 2015. An overview of methods to evaluate uncertainty of deterministic models in decision support. Environmental Modelling \& Software 63: 24-31.

Wilen JE. 2000. Renewable resource economists and policy: What differences have we made? Journal of Environmental Economics and Management 39: 306-327. 


\section{APPENDIX 1}

The dynamics of the population structure of the Pacific sardine was modeled using the following equation:

$$
N_{j+1, t+1}=N_{j, t} e^{-\left(M+F_{j, t}\right)}
$$

where $N_{j, t}$ is the number of individuals from age $j$ at time $t$ in years; $M$ is natural mortality parameters was taken from Morales-Bojórquez (1999) and it was assumed as constant over time and age; and $F_{j, t}$ is fishing mortality from age $j$ at time $t$ in years, which is defined as:

$$
F_{j, t}=f_{t} q
$$

where $f_{t}$ is the fishing effort, in fishing-days at time $t$, and $q$ is the catchability coefficient, the value of this parameter ( $q=$ 0.000155) was taken from Martínez-Aguilar (2006), which was computed as a weighted average value of the catchability-atlength estimates, and was assumed to be constant with time and age, the rate of fishing mortality is the same for all age groups.

The feedback expression (see eq. 1 above) is estimated from recruitment $R_{t}$ :

$$
N_{1, t}=R_{t}
$$

where $R_{t}$ was the number of recruits estimated by the environmentally driven stock-recruitment function (Ricker 1975; Hilborn \& Walters 1992) as follows:

$$
R_{t+1}=a S_{t} e^{-b S_{t}} e^{-c\left(M E I_{t}\right)} e^{\varepsilon}
$$

where $S_{t}$ is the spawning stock at year $t ; a$ is the densityindependent coefficient; $b$ is the density-dependent coefficient; $c$ is the coefficient that reflects the effects of environmental changes; $M E I_{t}$ is the environmental variable (in this case the multivariate index of ENSO at time $t$ ) (http://www.noaa.gov/); and $\varepsilon$ is the unexplained residual that is assumed to be normally distributed, $\varepsilon \sim N\left(0, \sigma^{2}\right)$. For the present work, the age of recruitment was defined as one year of age and the spawning stock comprised individuals between the ages of 2 and 6 years (Félix-Uraga 1990, 1992).

Total biomass was calculated using the following equation:

$$
B_{t}=\sum_{j=1}^{\text {Mage }} N_{j, t} W_{j}
$$

where Mage is the maximum age of the species (7 years), and $W_{j}$ represents the individual weight of species at different ages (j), estimated through the von Bertalanffy's growth function and the corresponding length-weight relationship.

The dynamics of the fishing fleet were modeled using the function described by Smith (1969), which assumes that effort responds to changes on the revenue, in such a way that increased revenues will generate and incentivize increases in fishing effort or viceversa:

$$
f_{t+1}=f_{t}+\left(\varphi \pi_{t}\right)
$$

where $\varphi$ is the fleet dynamics parameter which is greater than zero (if $\varphi$ is equal to zero, then effort is constant throughout time); and $\pi_{t}$ represents the net revenue in US dollars (USD) at time $t$.

The catch, $C_{j, t}$, was calculated using the standard catch equation (Baranov 1918):

$$
C_{t}=\sum_{j=1} B_{j, t}\left(\frac{F_{t}}{F_{t}+M}\left(1-e^{-\left(F_{t}+M\right)}\right)\right)
$$

where $B_{j, t}$ is the biomass for age $j$ at time $t$.

The net revenues at time $t(\pi)$ were calculated using the expression:

$$
\pi_{t}=T R_{t}-T C_{t}
$$

where $T R_{t}$ are the total revenue at time $t$, and $T C_{t}$ are the total costs at time $t$.

Total revenues were estimated, considering the catch and price of Pacific sardine (target specie) and others species (nontargeted species) in the landings:

$$
T R_{t}=\left(\left(P_{p s} \bullet C_{t}\right)+\left(P_{o s} \bullet \bar{C}_{o s}\right)\right)
$$

where $P_{p s}$ is the price per ton of Pacific sardine; $C_{t}$ is the catch of Pacific sardine at time $t$ (eq. 7); $P_{o s}$ is the price per ton of other species; $C_{o s, t}$ is the average catch of other species at time $t$.

The total costs at time $t$ (eq. 8) were calculated considering the fixed costs (investment costs of the boat and fishing equipment, depreciation, insurance of the boat and administrative costs), variable costs (foods, fuel, lubricant, repair of fishing gear, maintenance), and opportunity costs of labor and capital. From this value, the travel cost of a fishing day $(U c)$ and the total number of fishing day in year $t$ were estimated:

$$
T c_{t}=U c * f_{t}
$$

Cost and price data were obtained from direct interviews with fishermen and fishing fleet owners.

Net-Present-Value $(N P V)$ was defined as:

$$
N P V=\sum_{t=0}^{n} \frac{T R_{t}-T C_{t}}{(1+\delta)^{t}}
$$


where $n$ is the total span of years used in the simulation run, and $\delta$ is the discount rate (4\% for this study). This value was obtained subtracting the inflation to the interest generated by
Treasury Certificates (CETES, by its abbreviation in Spanish) to December 2004. CETES are instruments of debt that the Mexican Government emits to be financed.

Appendix 2.- Input parameters for the bioeconomic model of the Pacific sardine fishery on the western coast of the Baja California peninsula, Mexico / Parámetros de entrada para el modelo bioeconómico de la pesquería de sardina del Pacífico en la costa occidental de la península de Baja California, México

\begin{tabular}{|c|c|c|c|}
\hline Symbol & Description & Value & Source \\
\hline$W \infty$ & $\begin{array}{c}\text { Maximum weight of the Von Bertalanffy } \\
\text { equation }\end{array}$ & $86.4^{\mathrm{a}} \mathrm{g}$ & Félix-Uraga (1990) \\
\hline$K$ & $\begin{array}{c}\text { Growth coefficient of the Von Bertalanffy } \\
\text { equation }\end{array}$ & 0.99681 year $^{-1}$ & Félix-Uraga (1990) \\
\hline$t_{0}$ & $\begin{array}{c}\text { Parameter of the Von Bertalanffy } \\
\text { equation }\end{array}$ & -0.01542 year $^{-1}$ & Félix-Uraga (1990) \\
\hline Mage & Maximum age & 7 years & Félix-Uraga (1986) \\
\hline$s$ & Age at first reproduction & 2 years & Félix-Uraga (1986) \\
\hline$R_{\text {initial }}$ & Initial recruitment & $1,672,727,273$ ind. & De Anda-Montañez et al. (2010) \\
\hline$a$ & Density-independent coefficient & $83,250,670$ & De Anda-Montañez et al. (2010) \\
\hline$b$ & Density-dependent coefficient & 0.01108 & De Anda-Montañez et al. (2010) \\
\hline$c$ & Environmental changes parameter & -0.46669 & De Anda-Montañez et al. (2010) \\
\hline$M$ & Natural mortality rate & 0.60 year $^{-1}$ & Morales-Bojórquez et al. (1999) \\
\hline$q$ & Catchability coefficient & 0.00015 fishing day ${ }^{-1}$ & De Anda-Montañez et al. (2010) \\
\hline$\varphi$ & Fleet dynamics parameter & 0.00024 fishing day $\$ U^{-1}$ & De Anda-Montañez et al. (2010) \\
\hline$P_{p s}$ & Price for target species & $52.60 \$$ US ton $^{-1}$ & De Anda-Montañez et al. (2010) \\
\hline$P_{o s}$ & Price for non-target species & $36.36 \$ \mathrm{US} \mathrm{ton}^{-1}$ & De Anda-Montañez et al. (2010) \\
\hline$U c$ & Unit cost of fishing effort & $2200 \$$ US fishing day ${ }^{-1}$ & De Anda-Montañez et al. (2010) \\
\hline$\delta$ & Discount rate & 0.04 year $^{-1}$ & De Anda-Montañez et al. (2010) \\
\hline
\end{tabular}

${ }^{\mathrm{a}}$ This value was obtained by transforming the value reported by the author and by using the equation of non-isometric growth $a, b$ and $c$ are parameters of the stock-recruitment Ricker's equation

Table adapted from De Anda-Montañez et al. (2010) 